\title{
ANALISIS KLASTER DURIAN (Durio zibethinus Murr.) UNGGUL LOKAL DI KABUPATEN JEMBER DAN BANYUWANGI
}

(Cluster Analysis of Local Superior Durian (Durio zibethinus Murr.) in Jember and Banyuwangi District)

\author{
VEGA KARTIKA SARI $^{1 *}$, SEPDIAN LURI ASMONO ${ }^{2}$, EVA ROSDIANA $^{2}$ \\ ${ }^{1}$ Program Studi Agronomi, Fakultas Pertanian, Universitas Jember, \\ Jl. Kalimantan No. 37, Kotak Pos 159, Jember 68121 \\ ${ }^{2} J u r u s a n$ Produksi Pertanian, Politeknik Negeri Jember, \\ Jl. Mastrip, Kotak Pos 164, Jember 68124 \\ *Email: vegakartikas@unej.ac.id
}

\begin{abstract}
Indonesia is one of the centers of durian diversity in the world and one of the regions that makes durian a superior local fruit crop is Jember and Banyuwangi. Clustering is useful to facilitate the search for certain features of the type of durian. This study aims to determine the durian grouping in two districts namely Jember and Banyuwangi. The materials used were local superior durian fruit and characterization questionnaire. Research using descriptive methods. Characterization data will be analyzed using NTSYS software. The results showed that local superior durian fruit were grouped into 2 groups based on morphological characters. Cluster 1 consists of 4 durians namely Klemben, Hijau, Bajul, and Lambau. Cluster 2 only consists of durian Musang King. Based on the chemical content of durian fruit, durian Lambau from Jember has the highest water content of $75.52 \%$, Musang King from Banyuwangi has a fat content (2.29\%), Bajul from Jember has the highest fiber content (11.89\%), and Hijau from Banyuwangi has the highest protein (3.14\%) and sugar (26.08\%) content. Based on PCA showed that Musang King and Hijau have similirity on some morphological characters and chemical fruit contents. The results of correlation analysis of morphological characters and chemical content of durian fruit showed that leaf length was positively correlated with leaf width and protein content. Leaf width is positively correlated with sugar content. Fruit weight is positively correlated with water content.
\end{abstract}

Keywords : Chemical fruit content, Clustering, Morphology, Musang King

\section{PENDAHULUAN}

Durian (Durio zibethinus Murr.) merupakan tanaman buah tropis eksotis yang bernilai ekonomis tinggi dan berpotensi besar untuk dikembangkan. Indonesia merupakan salah satu pusat keanekaragaman durian di dunia (Belgis et al., 2016) dan salah satu daerah yang menjadikan durian sebagai tanaman buah lokal unggulan ialah daerah Karisidenan Besuki, Provinsi Jawa Timur. Karisidenan Besuki terdiri atas beberapa kabupaten yang menjadikan durian sebagai buah unggulan lokal, antara lain Banyuwangi dan Jember.

Durian memiliki karakter morfologi yang beraneka ragam (Sundari et. al., 2015). Belgis et al. (2016) menambahkan, keragaman durian terletak pada rasa, aroma, tekstur dan warna daging buah, serta pada bentuk dan ukuran buah. Durian lokal masing-masing kabupaten di Karisidenan Besuki memungkinkan memiliki keunggulan yang berbeda pada aspek morfologi dan kimiawi buahnya. Karakter yang beraneka ragam tersebut dapat digunakan untuk mengklasterkan durian. Cevallos et al. (2009) menambahkan, karakteristik rasa/organoleptik merupakan salah satu parameter yang sangat penting dalam pemuliaan tanaman dan sering menjadi pertimbangan utama dalam pengembangan suatu kultivar. Pengklasteran berguna untuk mempermudah pencarian ciri tertentu dari suatu jenis durian (Vanijajiva, 2012). Pengklasteran juga bertujuan untuk mengelompokkan objek berdasarkan karakteristik yang dimilikinya (Bayu dan Ashari, 2019). Sehubungan dengan hal tersebut, maka penelitian ini dilakukan untuk mengetahui pengklasteran durian unggul lokal di Kabupaten Jember dan Banyuwangi berdasarkan karakter morfologi dan kandungan kimiawi buah. 


\section{BAHAN DAN METODE}

Penelitian dilaksanakan pada bulan Januari sampai Maret 2020. Pengambilan sampel dilakukan di dua kabupaten, yakni Kabupaten Jember dan Banyuwangi.

Bahan yang digunakan ialah 5 macam durian unggul lokal hasil survei dan wawancara dengan petani durian setempat. Buah durian yang ditemukan antara lain, Klemben, Hijau, Bajul, Musang King, dan Lambau. Durian unggul lainnya masih memungkinkan untuk ditemukan lagi mengingat masih banyak pohon durian yang belum berbuah saat pelaksanaan survei. Bahan yang dibutuhkan untuk analisis kimiawi buah yaitu aquades, alkohol, pelarut lemak, larutan asam borat $\mathrm{H}_{2} \mathrm{BO}_{3} 2 \%$, larutan asam klorida $0,01 \mathrm{~N}$, larutan natrium hidroksida $\mathrm{N}_{\mathrm{a}} \mathrm{OH} 30 \%$, tissue, masker, dan sarung tangan.

Alat yang digunakan untuk karakterisasi morfologi tanaman dan buah antara lain alat tulis, penggaris, kamera digital, dan deskriptor. Untuk analisis kimiawi buah diperlukan gelas ukur, erlenmeyer, pipet, seperangkat alat titrasi, mortal dan pestle, labu lemak, alat soxhlet, pemanas listrik, kertas whatmann no.41, timbangan analitik, mikropipet, spektrofotometer, oven, eksikator, pendingin corong Buchner, pompa vakum, labu kjedhal $100 \mathrm{ml}$, alat penyulingan dan kelengkapannya, dan refraktometer analitik.

Metode penelitian dilakukan dengan mengkarakterisasi karakter morofologi dan kandungan kimiawi buah yang diidentifikasi saat buah masak optimal. Karakter morfologi yang diidentifikasi sebanyak 26 karakter sesuai Descriptors for Durian yang dikeluarkan IPGRI (Bioversity, 2007). Analisa kandungan kimiawi buah durian meliputi analisa kadar air menggunakan metode oven, kadar lemak menggunakan metode ekstraksi langsung soxhlet, serat kasar menggunakan metode ekstraksi asam basa, protein menggunakan metode semi mikro kjeldhal, dan kadar gula menggunakan metode Anthrone.

Data hasil karakterisasi dianalisis klaster menggunakan software NTSYS-pc 2.02 untuk menyusun dendogram. Data kuantitatif juga dianalisis menggunakan progam SAS 9.1 for windows untuk menghitung korelasi antara karakter morfologi dan kimiawi buah dan menyusun grafik persebaran berdasarkan analisis komponen utama (Principles Component Analysis/PCA).

\section{HASIL DAN PEMBAHASAN}

Hasil karakterisasi kuantitatif dan kualitatif buah durian disajikan pada Tabel 1 dan 2 .

Tabel 1. Keragaman karakter kualitatif durian unggulan lokal

\begin{tabular}{|c|c|c|c|c|c|c|c|}
\hline Aksesi & $\begin{array}{c}\text { Bentuk } \\
\text { tajuk } \\
\text { pohon }\end{array}$ & $\begin{array}{c}\text { Bentuk } \\
\text { buah }\end{array}$ & $\begin{array}{l}\text { Bentuk } \\
\text { duri }\end{array}$ & $\begin{array}{c}\text { Kerapatan } \\
\text { duri }\end{array}$ & $\begin{array}{c}\text { Warna kulit } \\
\text { buah }\end{array}$ & $\begin{array}{c}\text { Aril cream } \\
\text { ness }\end{array}$ & Rasa \\
\hline Bajul & $\begin{array}{l}\text { Tidak } \\
\text { teratur }\end{array}$ & Bulat telur & Convex & Agak rapat & $\begin{array}{l}\text { Oranye } \\
\text { kekuningan }\end{array}$ & Sangat & Manis \\
\hline Lambau & $\begin{array}{l}\text { Setengah } \\
\text { membulat }\end{array}$ & Bulat telur & Concave & Jarang & $\begin{array}{l}\text { Hijau } \\
\text { kekuningan }\end{array}$ & Sedang & $\begin{array}{l}\text { Kurang } \\
\text { manis }\end{array}$ \\
\hline Musangking & Piramida & $\begin{array}{l}\text { Bulat } \\
\text { panjang }\end{array}$ & Hooked & Agak rapat & Oranye & Cukup & $\begin{array}{l}\text { Manis } \\
\text { pahit }\end{array}$ \\
\hline Hijau & Lonjong & Lonjong & Concave & Jarang & $\begin{array}{l}\text { Hijau } \\
\text { kecoklatan }\end{array}$ & Kurang & Manis \\
\hline Si Klemben & Piramida & Belimbing & Conical & Rapat & Coklat & Kurang & $\begin{array}{l}\text { Manis } \\
\text { pahit }\end{array}$ \\
\hline
\end{tabular}

Tabel 2. Keragaman karakter kuantitatif durian unggulan lokal

\begin{tabular}{llllllll}
\hline \multicolumn{1}{c}{ Aksesi } & $\begin{array}{c}\text { Panjang } \\
\text { daun }\end{array}$ & $\begin{array}{c}\text { Lebar } \\
\text { daun }\end{array}$ & $\begin{array}{c}\text { Panjang } \\
\text { tangkai } \\
\text { buah }\end{array}$ & $\begin{array}{c}\text { Panjang } \\
\text { duri }\end{array}$ & $\begin{array}{c}\text { Bobot } \\
\text { buah }\end{array}$ & $\begin{array}{c}\text { Ketebalan } \\
\text { aril }\end{array}$ & $\begin{array}{c}\text { Jumlah } \\
\text { biji per } \\
\text { buah }\end{array}$ \\
\hline Bajul & 13,5 & 4,0 & 6,0 & 1,3 & 1,8 & 0,8 & Sedang \\
Lambau & 14,5 & 14,5 & 5,5 & 1,0 & 3,5 & 0,8 & Banyak \\
Musangking & 18,5 & 18,0 & 5,5 & 1,1 & 1,5 & 1,0 & Sedikit \\
Hijau & 17,5 & 17,5 & 6,5 & 1,1 & 2,1 & 0,8 & Banyak \\
Si Klemben & 13,0 & 13,0 & 4,0 & 1,5 & 1,2 & 0,2 & Sedikit \\
\hline
\end{tabular}

Keterangan: jumlah biji sedikit $=<10$, sedang $=10-20$, banyak $=>20$ 
Rasa durian lokal pada aksesi yang diuji ini beragam mulai dari kurang manis, manis, dan manis pahit. Menurut Zanariah and Rehan (1987) dalam Belgis et al. (2016), adanya rasa pahit pada buah durian diduga dipengaruhi oleh adanya beberapa asam amino yang memiliki rasa pahit, seperti alanine, proline, phenylalanine dan isoleucine. Menurut Haryanto dan Royaningsih (2003), salah satu karakter durian unggul dicirikan dari bobot buah 1,5-2,0 kg dan jumlah biji sedikit. Berdasarkan Tabel 2 yang memenuhi kriteria tersebut ialah Musangking. Salah satu karakter yang umumnya mempengaruhi preferensi konsumen ialah tekstur aril atau tekstur daging buah. Sebagian besar ketebalan aril pada penelitian ini berkisar $0,6-2,0 \mathrm{~cm}$, dan hanya $\mathrm{Si}$ Klemben yang memiliki ketebalan aril $<0,5 \mathrm{~cm}$. Keragaman bentuk buah, kerapatan duri, dan warna kulit buah dari durian lokal disajikan pada Gambar 1, dan warna aril pada Gambar 2.

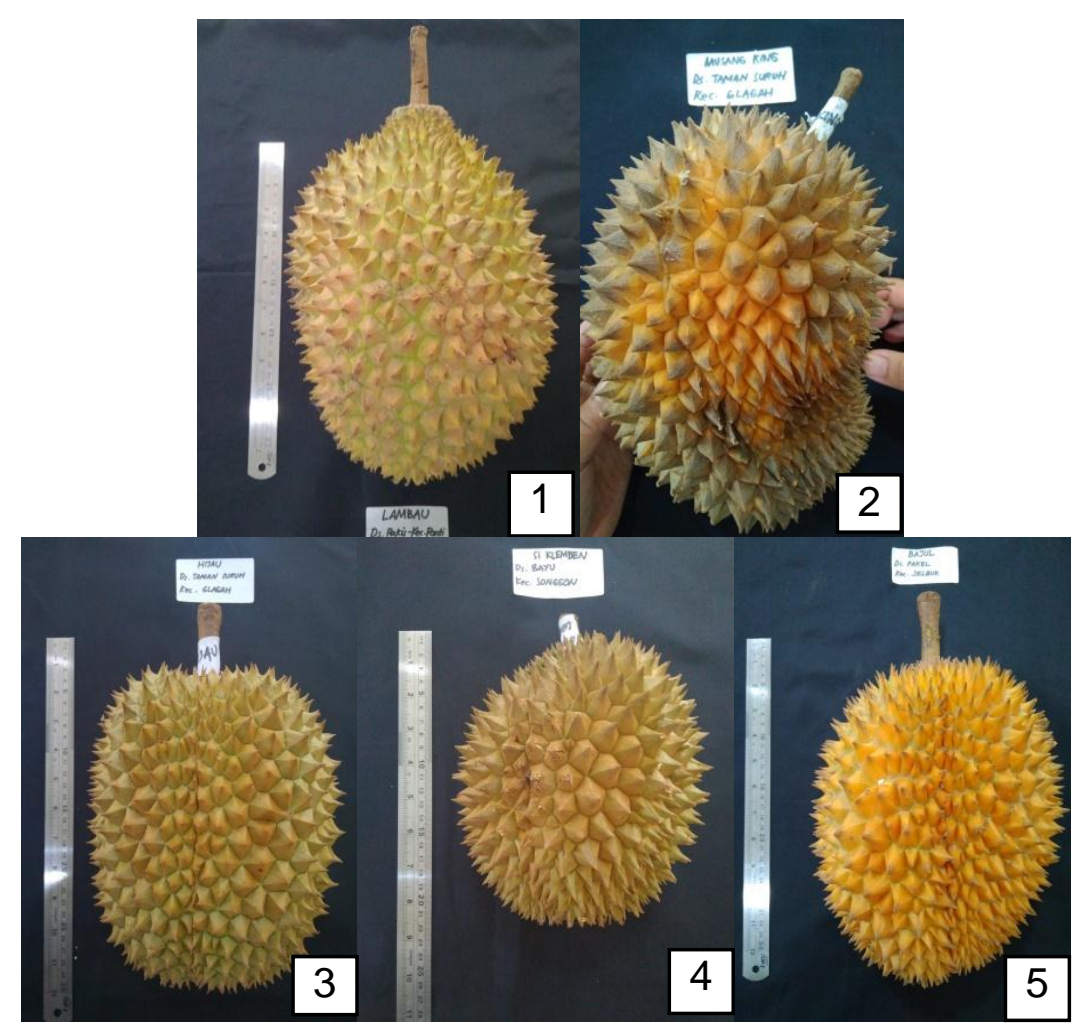

Gambar 1. Keragaman bentuk buah, warna kulit buah dan kerapatan duri durian unggulan lokal Kab. Jember dan Banyuwangi (1. Lambau, 2. Musangking, 3. Hijau, 4. Si Klemben, 5. Bajul)
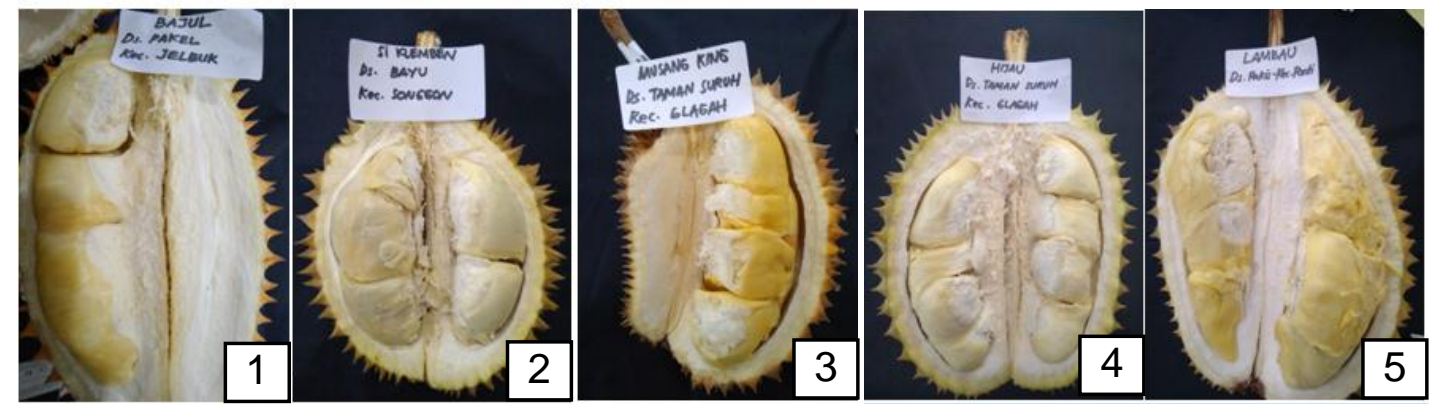

Gambar 2. Warna daging buah durian unggulan lokal Kab. Jember dan Banyuwangi (1. Bajul, 2. Si Klemben, 3. Musangking, 4. Hijau, 5. Lambau)

Hasil uji gerombol diperoleh dendogram dengan kemiripan sebesar $72,5 \%$ (Gambar 3). Hal tersebut menunjukkan antara durian unggul lokal yang berasal dari kabupaten Jember dan dari kabupaten Banyuwangi memiliki hubungan kekerabatan 
yang cukup besar. Antar aksesi durian unggulan lokal dari dua kabupaten tersebut memiliki persamaan karakter kuantitatif maupun kualitatif dari morfologinya, yakni bentuk daun lonjong, bentuk tepi daun rata, warna tangkai buah coklat, permukaan buah berduri, panjang duri sedang berkisar 1,1-1,5 $\mathrm{cm}$, intensitas warna kulit buah terang, intensitas warna daging buah terang, dan warna biji kuning kecoklatan.

Berdasarkan dendogram tersebut terbentuk dua kelompok besar yaitu kelompok I terdiri 4 aksesi dan kelompok II terdiri Musangking saja dari Banyuwangi. Hal tersebut menunjukkan Musangking memiliki keunikan morfologi yang membedakan dengan aksesi lainnya, yaitu permukaan batang yang halus, kepadatan percabangan yang tidak terlalu rapat, lebar daun yang lebih lebar dari pada aksesi lainnya yaitu berkisar 6,1-9,0 cm, bentuk dasar daun agak oval (cuneate), bentuk ujung buah melengkung kedalam depressed, bentuk duri runcing melengkung (hooked), warna kulit buah oranye, warna daging buah oranye, tekstur aril sedikit berserat dan cukup lembut (creaminess), dan warna biji krem kecoklatan.

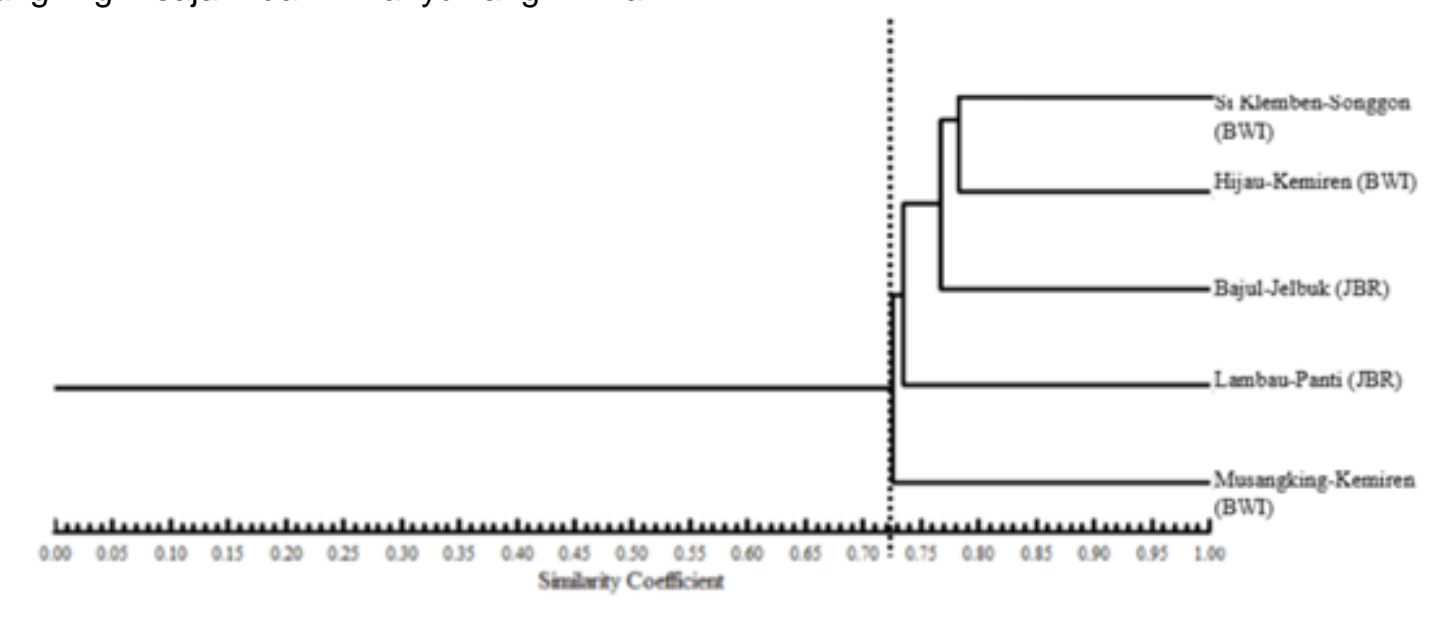

Gambar 3. Dendogram kemiripan berdasarkan karakter morfologi

Tabel 3. Hasil Analisa kandungan kimiawi buah durian

\begin{tabular}{llllll}
\hline Karakter & \multicolumn{5}{c}{ Aksesi } \\
\cline { 2 - 6 } & Si Klemben & Lambau & Hijau & Si Bajul & Musangking \\
\hline Kadar air (\%) & 61,71 & 75,52 & 63,97 & 74,50 & 62,17 \\
Kadar lemak (\%) & 2,12 & 1,73 & 2,21 & 2,24 & 2,29 \\
Kadar serat (\%) & 11.16 & 10,56 & 9,26 & 12,00 & 11,89 \\
Kadar protein (\%) & 2,67 & 3,08 & 3,14 & 2,23 & 2,86 \\
Kadar gula total (\%) & 23,98 & 14,90 & 26,08 & 16,79 & 21,48 \\
\hline
\end{tabular}

Kandungan kimiawi buah durian disajikan pada Tabel 3. Kadar air dari 5 kultivar durian berkisar $61,71-75,52 \%$. Menurut Belgis et al. (2016), kadar air merupakan salah satu karakter fisikokimia penting, karena mempengaruhi rasa, tekstur, tampilan dan daya simpan. Tingginya kandungan air pada kultivar durian mengakibatkan durian memiliki daya simpan yang singkat. Hal tersebut menunjukkan aksesi Lambau tidak dapat disimpan lama dibandingkan aksesi $\mathrm{Si}$ Klemben. Menurut Haryanto dan Royaningsih, (2003) durian unggul lainnya seperti Menoreh Kuning memiliki kadar air 66\%; dan durian Sunan mencapai 70,64\%.
Kadar lemak tertinggi dimiliki oleh Musangking. Menurut Kupirovic et al. (2012), terdapat korelasi positif antara kandungan lemak dengan sensasi mengunyah. Lemak yang dikandung suatu produk bersentuhan dengan lidah dan langit-langit akan mempengaruhi dampak sensorik dari produk tersebut. Musangking lebih populer daripada 4 aksesi lainnya, didukung dengan penelitian ini bahwa Musangking memiliki kelebihan pada kandungan lemak yang mempengaruhi selera konsumen. 
Tabel 4. Hasil Analisa korelasi fisikokimia durian

\begin{tabular}{|c|c|c|c|c|c|c|c|c|c|}
\hline & $\begin{array}{l}\text { Panjang } \\
\text { daun }\end{array}$ & $\begin{array}{l}\text { Lebar } \\
\text { daun }\end{array}$ & $\begin{array}{l}\text { Panjang } \\
\text { tangkai } \\
\text { buah }\end{array}$ & $\begin{array}{l}\text { Panjang } \\
\text { duri }\end{array}$ & $\begin{array}{l}\text { Bobot } \\
\text { buah }\end{array}$ & $\begin{array}{l}\text { Kadar } \\
\text { Air }\end{array}$ & $\begin{array}{l}\text { Kadar } \\
\text { Lemak }\end{array}$ & $\begin{array}{l}\text { Kadar } \\
\text { Serat }\end{array}$ & $\begin{array}{l}\text { Kadar } \\
\text { Protein }\end{array}$ \\
\hline Lebar daun & 0.6966 & & & & & & & & \\
\hline $\begin{array}{l}\text { Panjang } \\
\text { tangkai } \\
\text { buah }\end{array}$ & 0.4232 & 0.3173 & & & & & & & \\
\hline $\begin{array}{l}\text { Panjang } \\
\text { duri }\end{array}$ & -0.5 & -0.5462 & -0.6682 & & & & & & \\
\hline Bobot buah & -0.3281 & -0.05 & 0.3117 & -0.6318 & & & & & \\
\hline Kadar Air & -0.5862 & -0.5073 & 0.303 & -0.2874 & 0.7786 & & & & \\
\hline $\begin{array}{l}\text { Kadar } \\
\text { Lemak }\end{array}$ & 0.0704 & 0.3266 & 0.1693 & 0.3378 & -0.5514 & -0.3511 & & & \\
\hline $\begin{array}{l}\text { Kadar } \\
\text { Serat }\end{array}$ & -0.055 & -0.2991 & -0.3388 & 0.3437 & -0.4712 & -0.011 & 0.1746 & & \\
\hline $\begin{array}{l}\text { Kadar } \\
\text { Protein }\end{array}$ & 0.7824 & 0.3718 & 0.118 & -0.4239 & -0.1025 & -0.4812 & -0.487 & -0.2638 & \\
\hline Kadar Gula & 0.4196 & 0.4857 & -0.0834 & 0.2968 & -0.6089 & -0.866 & 0.4812 & -0.3799 & 0.3145 \\
\hline
\end{tabular}

Hubungan antara morfologi buah dan kandungan kimiawi buah dapat ditentukan melalui analisis korelasi. Berdasarkan hasil analisis (Tabel 4) diketahui bahwa panjang daun berkorelasi positif dengan lebar daun (69\%) dan (78\%) dengan kadar protein. Hal tersebut sesuai dengan hasil penelitian Baroroh et al. (2014), lebar dan panjang daun saling berkorelasi dengan nilai $69 \%$. Panjang daun berkorelasi dengan kadar protein. Menurut Gardner (1991), protein diproduksi melalui proses respirasi yang memanfaatkan hasil fotosintesis. Semakin panjang dan lebar daun akan mempengaruhi hasil fotosintesis. Lebar daun berkorelasi positif dengan kadar gula dengan nilai korelasi $48 \%$. Hal tersebut berarti semakin besar lebar daun maka semakin tinggi kadar gula daging buah durian. Panjang duri berkorelasi negatif dengan bobot buah dengan nilai korelasi $63 \%$. Bobot buah berkorelasi positif $(77 \%)$ dengan kadar air dan berkorelasi negatif $(60 \%)$ dengan kadar gula, yang berarti semakin besar bobot buah maka kadar air daging buah semakin tinggi, namun kadar gula semakin rendah. Hal tersebut sesuai yang diungkapkan
Berdasarkan hasil analisis komponen utama (PCA) dari 10 karakter yang terdiri atas karakter morfologi dan kimiawi buah dari 5 aksesi durian diperoleh tiga komponen utama yang mampu menerangkan keragaman kumulatif sebesar $83 \%$ dari keragaman total. komponen utama 1 terdiri atas karakter panjang daun, lebar daun, kadar protein dan kadar gula. Karakter penyusun komponen utama 2 terdiri dari karakter bobot buah dan kadar air. Karakter penyusun komponen utama 3 terdiri atas panjang tangkai buah dan kadar lemak. Pengelompokan berdasarkan komponen penyusunnya disajikan dalam bentuk scatter plot pada Gambar 4.

Berdasarkan tiga komponen penyusun PCA menunjukkan bahwa durian Hijau dan Musangking berada dalam satu kelompok, yang berarti bahwa aksesi-aksesi tersebut memiliki kemiripan karakter morfologi dan kimiawi. Hijau dan Musangking berasal dari daerah sama yaitu Kecamatan Kemiren, Kabupaten Banyuwangi. 

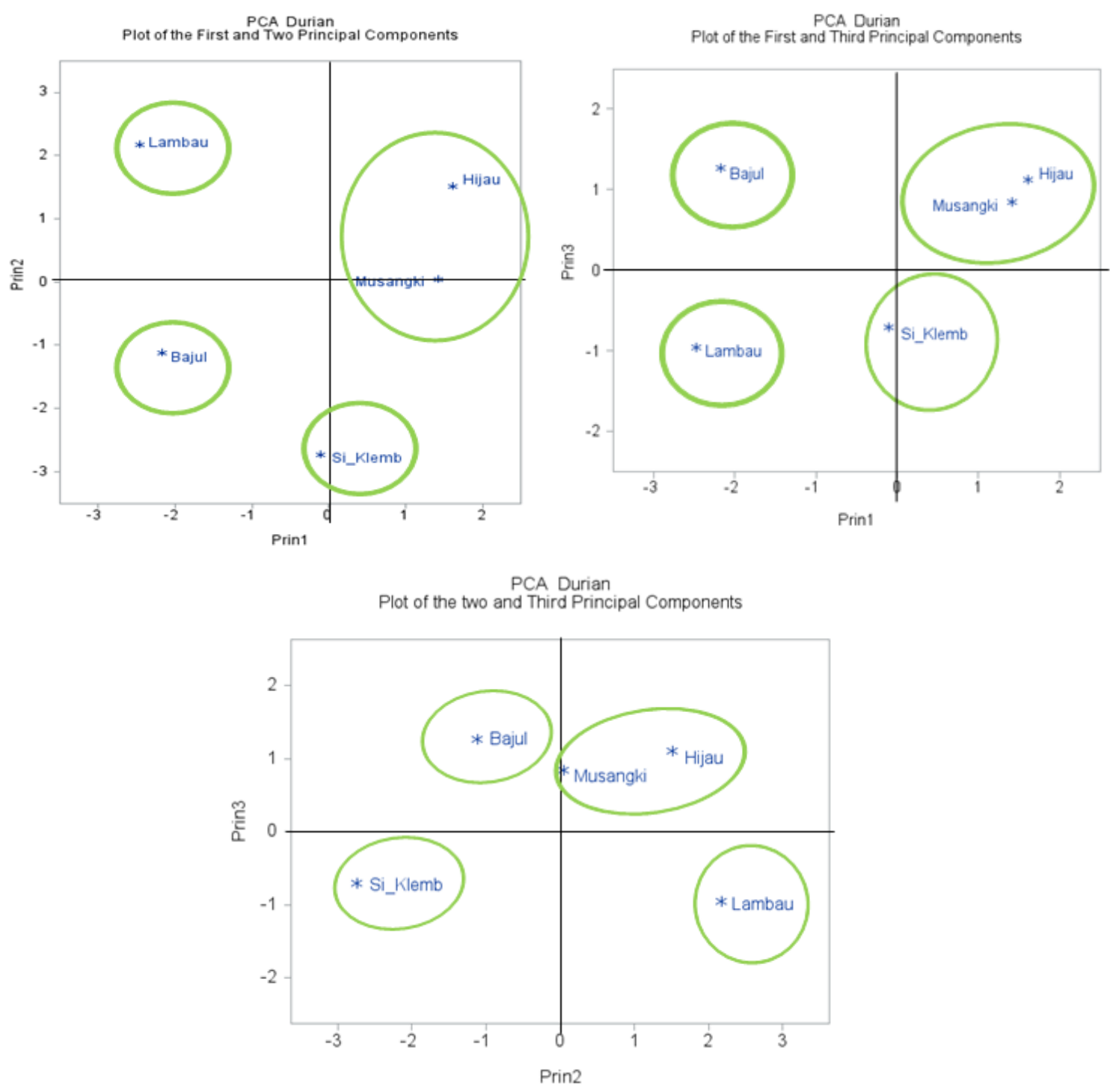

Gambar 4. Hasil PCA berdasarkan komponen 1 dan 2; hasil PCA berdasarkan komponen 1 dan 3; dan hasil PCA berdasarkan komponen 2 dan 3

\section{KESIMPULAN DAN SARAN}

Berdasarkan dendogram karakter morfologi tanaman durian unggulan lokal di Kabupaten Jember dan Banyuwangi menunjukkan nilai koefisien kemiripan sebesar $72,5 \%$. Pengelompokan terbagi menjadi 2 kelompok utama, kelompok 1 terdiri atas $\mathrm{Si}$ Klemben, Hijau, Bajul, Lambau, dan kelompok 2 terdiri atas Musangking. Berdasarkan kandungan kimiawi buah, dan prasyarat unggul daging durian, aksesi yang memiliki karakter unggul yaitu Musangking memiliki kadar lemak tertinggi, Hijau memiliki kadar gula total dan protein tertinggi, Si Klemben memiliki kadar air terendah dan Bajul memiliki kadar serat tertinggi. Panjang daun berkorelasi positif dengan lebar daun dan dengan kadar protein. Lebar daun berkorelasi positif dengan kadar gula. Panjang duri berkorelasi negatif dengan bobot buah. Bobot buah berkorelasi positif dengan kadar air dan berkorelasi negatif dengan kadar gula. Kadar air berkorelasi negatif dengan kadar gula. Berdasarkan hasil PCA dari beberapa komponen penyusun, Musangking dan Hijau berada pada kelompok yang sama. 


\section{DAFTAR PUSTAKA}

Baroroh, N., Fitmawati, N., dan Sofiyanti. 2014. Analisis Hubungan Kekerabatan Durian (Durio zibethinus Murr.) Berdasarkan Penanda Morfologi di Kabupaten Kuantan Singingi. JOM FMIPA 1(2):1-7.

Bayu, E.M. dan Ashari, S. 2019. Analisis Klaster Durian Unggul Lokal di Kecamatan Kasembon. Jurnal Produksi Pertanian. 7(7): 1347-1353

Belgis, M., Wijaya, C.H., Apriyantono, A., Kusbiantoro, B., and Yuliana, N.D. 2016. Physichemical differences and sensory profiling of six lai (Durio kutejensis) and four durian (Durio zibethinus) cultivars indigenous Indonesia. Inter. Food Research Journal, 23(4): 1466-1473.

Bioversity. 2007. Descriptors for Durian (Durio zibethinus Murr.). Bioversity International. Rome. Italy.

Cevallos, J.M., Corcuera, J.R., Etxeberria, E. 2009. Metabolomic analysis in food science: A review. Trends in Food Science \& Technology, 20(11): 557-566.

Gardner F.P., Pearce R.B., and Mitchell, R.L. 1991. Physiology of Crop Plants. Diterjemahkan oleh H. Susilo. Universitas Indonesia Press. Jakarta.

Haryanto, B. and Royaningsih, S. 2003. Relationship between durian maturity of Sunan and its physical properties. Agritech 23: 33-36.

Kupirovic, U.P., Godinot, N., Juillerat, M. A. and Raspor, P., 2012. Thickness of lipid deposition on oral surfaces depending on oil content and its influence on mouth feel perception. Food Technol. Biotechnol, 50: 461- 466.

Sundari, E.L., Arumingtyas, L., Hakim and R. Azrianingsih. 2015. Exploration and Morphological Character Identification of Local Durian (Durio zibenthinus Murr.) from Tidore Island, North Maluku. Internattional Conference on Global Resource Conservation (ICGRC). Proceeding of $6^{\text {th }}$ ICGRC.p. 1-4.

Vanijajiva, O. 2012. The Application of ISSR Markers in Genetic Variance Detection among Durian (Durio zibenthinus Murr.) Cultivars in The Nonthaburi Province, Thailand. Procedia Engineering, 32:155159. 
Analisis Klaster Durian Unggul Jember dan Banyuwangi (Sari, et al.) 